\title{
UNIJNY SYSTEM REJESTRÓW HANDLOWYCH I JEGO IMPLEMENTACJA DO PRAWA POLSKIEGO PO UCHWALENIU DYREKTYWY PARLAMENTU EUROPEJSKIEGO I RADY 2012/17/UE Z 13 CZERWCA 2012 R.
}

\section{WPROWADZENIE}

Krajowe reguły funkcjonowania rejestrów handlowych ${ }^{1}$ w państwach członkowskich UE są na obecnym etapie rozwoju prawa europejskiego mocno zróżnicowane ${ }^{2}$. Równie skomplikowana pozostaje kwestia ich wzajemnej współpracy, o ile do takiej w ogóle dochodzi. Wyróżnia się przy tym trzy zasadnicze obszary ekonomiczno-prawne, które są szczególnie wrażliwe na brak sprawnej wymiany informacji pomiędzy krajowymi rejestrami handlowymi: 1) istnienie oddziałów spółek z siedzibą w innym państwie członkowskim niż oddział, 2) transgraniczne procesy restrukturyzacyjne spółek, 3) pozyskiwanie informacji o spółkach z siedzibą w innym państwie członkowskim ${ }^{3}$.

Pierwszy z wymienionych obszarów dotyczy relacji pomiędzy spółką a jej oddziałami utworzonymi za granica. Jeżeli pomiędzy rejestrami handlowymi nie istnieje sprawny system wymiany informacji, to może dojść do sytuacji, w której oddział spółki będzie działać pomimo wykreślenia spółki z rejestru

${ }^{1}$ Przez co w ramach opracowania rozumie się instytucje, których głównym zadaniem jest zbieranie, przetwarzanie (funkcja ewidencyjna) i publikowanie informacji w standardowej formie (funkcja informacyjna) przekazywanych przez podmioty zobowiązane, którymi są w szczególności spółki prawa handlowego. Z uwagi na zakres zastosowania omawianych w opracowaniu aktów prawa unijnego rozważania zostaną ograniczone do czynności rejestrowych mających za przedmiot działalność spółek kapitałowych. Szerzej na temat pojęcia rejestrów handlowych i pełnionych przez nie funkcji zob. w literaturze: E. Norek, Krajowy Rejestr Sqdowy, Warszawa 2001, s. 11 i n.; T. Stawecki, Rejestry przedsiębiorców w Europie, Warszawa 2004, s. 65 i n.; E. Marszałek-Krześ, w: S. Włodyka (red.), System prawa handlowego. Prawo handlowe - część ogólna, t. 1, Warszawa 2009, s. 1040-1041; w doktrynie niemieckiej zwłaszcza zob. A. Krafka, w: K. Schmidt (red.), Münchener Kommentar zum HGB, München 2005, s. 148-153.

2 T. Stawecki, op. cit., s. 24-30.

${ }^{3}$ Zob. dokument z 4 listopada 2009 r. Komisji Europejskiej: Impact Assessment Accompanying document to the Proposal for a Directive of the European Parliament and of the Council amending Directives 89/666/EEC, 2005/56/EC and 2009/101/EC as regards the interconnection of central, commercial and companies registers, SEC(2011) 222 final, s. 17-28, http://eur-lex.europa. eu/legal-content/EN/TXT/?uri=CELEX:52011 SC0222 [dostęp: 5.06.2016]. 
i utraty w ten sposób przez spółkę osobowości prawnej. Szacuje się, że w UE w takiej sytuacji znajduje się około $15 \%$ oddziałów ${ }^{4}$. Rodzi to poważne problemy dla oceny doniosłości prawnej czynności dokonanych przez taki oddział.

Drugi z problemów powstających na skutek braku ram prawnych określajacych warunki współpracy rejestrów handlowych związany jest z przeprowadzaniem transgranicznych procesów restrukturyzacyjnych, takich jak transgraniczne łączenia, podziały czy przekształcenia spółek. Nie ulega wątpliwości, że w przypadku braku szczegółowych przepisów i narzędzi umożliwiajaccych sprawną komunikacje pomiędzy instytucjami rejestrowymi ${ }^{5}$ cała procedura restrukturyzacji ulega wydłużeniu oraz wzrastają jej koszty, co w pewnym stopniu zniechęca podmioty gospodarcze do podjęcia decyzji o ekspansji na inne rynki europejskie.

Ostatecznie na prowadzenie transgranicznej działalności gospodarczej istotny wpływ ma dostarczenie kontrahentom wiarygodnej informacji na temat formy prawnej, w ramach której funkcjonuje dane przedsiębiorstwo. Jej źródłem są m.in. dane zawarte w publicznym rejestrze. Z racji tego, że każde państwo posiada własne reguły prowadzenia stosownych rejestrów handlowych oraz upubliczniania danych w nich zawartych, uzyskanie wartościowego pakietu informacji o zagranicznych podmiotach może w niektórych przypadkach okazać się per se kosztownym i czasochłonnym przedsięwzięciem.

Zdaniem Komisji Europejskiej działaniem niezbędnym dla przezwyciężenia opisanych przeszkód na terenie Unii było uchwalenie dyrektywy Parlamentu Europejskiego oraz Rady 2012/17/UE z 13 czerwca 2012 r. ${ }^{6}$ Termin transpozycji dyrektywy został wyznaczony na 7 lipca 2014 r., jednakże z uwagi na przyjęcie przez Komisję aktów wykonawczych, które zostały ogłoszone 10 czerwca 2015 r., pełna implementacja dyrektywy powinna nastapić w terminie 2 lat od dnia ogłoszenia ${ }^{7}$.

Mając na uwadze powyższe, poniższe rozważania będą koncentrować się na analizie i ocenie dyrektywy 2012/17/UE z perspektywy założonego celu polegającego na zacieśnieniu współpracy krajowych rejestrów handlowych ${ }^{8}$. Uwagę poświęcono również kwestii jej implementacji do polskiego prawa oraz skutków, jakie niesie dla rodzimych podmiotów gospodarczych.

\footnotetext{
${ }^{4}$ Ibidem, s. 20.

${ }^{5}$ Najczęściej odbywa się ona za pośrednictwem publicznych instytucji pocztowych oraz za pomocą treści, które wymagają dodatkowych tłumaczeń na język państwa destynacji korespondencji.

${ }^{6}$ Dyrektywa Parlamentu Europejskiego i Rady 2012/17/UE z 13 czerwca 2012 r. zmieniająca dyrektywę Rady 89/666/EWG i dyrektywy Parlamentu Europejskiego i Rady 2005/56/WE i 2009/101/WE w zakresie integracji rejestrów centralnych, rejestrów handlowych i rejestrów spółek, Dz. Urz. UE z 16 czerwca 2012 r., L 156/1 (dalej jako: dyrektywa 2012/17/UE).

${ }^{7}$ Art. 5 ust. 2 dyrektywy 2012/17/UE. Zob. E. Skibińska, Unijny Rejestr Spótek, „Monitor Prawniczy" 2012, nr 16, s. 842.

${ }^{8}$ Pojęcie unijnego systemu rejestrów handlowych należy odróżnić od szerszego pojęcia europejskich systemów rejestrów handlowych, które obejmuje również prywatne inicjatywy połączenia i współpracy rejestrów, np. EBR lub BRITE (zob. przyp. 13). Por. jednak z wypowiedzeniami w doktrynie niemieckiej, w której używane jest określenie „europejski system” (europäische System der Registervernetzung). Tak H. Oetker, Kommentar zum Handelsgesetzbuch (HGB), München 2015, s. 157.
} 


\section{WPLYW PRAWA UNII EUROEPJSKIEJ NA FUNKCJONOWANIE REJESTRÓW HANDLOWYCH PRZED 2012 R.}

Podstawową barierę dla funkcjonowania unijnego systemu rejestrów handlowych do $2012 \mathrm{r}$. stanowił brak wzajemnych powiązań pomiędzy poszczególnymi rejestrami państw członkowskich, popartych odpowiednimi regulacjami prawnymi ${ }^{9}$. Rozwiązaniem tej kwestii stało się uchwalenie dyrektywy 2012/17/UE, której celem nie było ustanowienie nowej dyrektywy prawa spółek ${ }^{10}$, lecz dokonanie zmian i uzupełnienie o nowe regulacje dyrektyw: 2009/101/WE ${ }^{11}$, jedenastej 89/666/EWG ${ }^{12}$ oraz dziesiątej 2005/56/ $\mathrm{WE}^{13}$.

Dyrektywa 2009/101/WE nakłada na państwa członkowskie obowiązek utworzenia stosownego rejestru spółek i nadania mu minimalnych ram prawnych. Szczegółowe przepisy dotyczące procedury rejestracji oraz rodzaju organu prowadzącego taki rejestr zostały pozostawione w gestii państw członkowskich $^{14}$. Zgodnie z treścią dyrektywy dokumenty stanowiące „konstytucję” spółki, tj. określające jej wewnętrzną strukturę, relacje pomiędzy organami i udziałowcami oraz sposób reprezentacji spółki, a ponadto dokumenty księgowe oraz informacje o niektórych istotnych zdarzeniach, np. likwidacji spółki,

${ }^{9}$ Należy nadmienić, że przed uchwaleniem dyrektywy 2012/17/UE w Europie pojawiały się inicjatywy dążące do połączenia funkcjonowania europejskich rejestrów. Pierwszą z nich był projekt EBR (European Business Register), rozpoczęty w 1992 r., którego zadaniem było udostępnienie informacji o spółkach podlegających prawu jednego z państw biorących udział w projekcie. Szerzej na temat projektu EBR zob. dokument Komisji z 4 listopada 2009 r.: Progress Report Accompanying document to the Green Paper The interconnection of business registers, SEC(2009) 1492, s. 7-11, http://ec.europa.eu/internal_market/consultations/docs/2009/ interconnection_of_business_registers/working_document_en.pdf [dostęp: 5.06.2016]. Kolejną inicjatywą był tworzony w latach 2006-2009 BRITE (Business Register Interoperability throughout Europe), którego celem z kolei było wprowadzenie rozwiązań technologicznych pozwalających na wymianę informacji pomiędzy rejestrami krajowymi. BRITE miał usprawnić przeprowadzanie procesów transgranicznych (łączeń, podziałów i przekształceń), a także zwiększyć kontrolę nad funkcjonowaniem oddziałów spółek zagranicznych. Szer. zob. ibidem, s. 11-15.

${ }_{10}$ T. Kilian, EU-Richtlinie zur Verknüpfung der Handelsregister verabschiedet, „FGPrax Praxis der Freiwilligen Gerichtsbarkeit” 2012, s. 185.

${ }_{11}$ Dyrektywa 2009/101/WE Parlamentu Europejskiego i Rady z 16 września 2009 r. w sprawie koordynacji gwarancji, jakie są wymagane w państwach członkowskich od spółek w rozumieniu art. 54 akapit drugi Traktatu, w celu uzyskania ich równoważności, dla zapewnienia ochrony interesów zarówno wspólników, jak i osób trzecich, Dz. Urz. UE z 1 października 2009 r., L 258/11, uchylająca dyrektywę 68/151/ EWG Rady z 9 marca 1968 r. w sprawie koordynacji gwarancji, jakie są wymagane w państwach członkowskich od spółek w rozumieniu art. 58 akapit drugi Traktatu, w celu uzyskania ich równoważności w całej Wspólnocie, dla zapewnienia ochrony interesów zarówno wspólników, jak i osób trzecich, Dz. Urz. WE z 14 marca 1968 r., L 65/8, zmieniona przez dyrektywę 2003/58/WE Parlamentu Europejskiego i Rady z 15 czerwca 2003 r., Dz. Urz. UE z 4 września 2003 r., L 221/13.

${ }^{12}$ Dyrektywa Rady 89/666/EWG z 21 grudnia 1989 r. dotycząca wymogów ujawniania informacji odnośnie do oddziałów utworzonych w państwie członkowskim przez niektóre rodzaje spółek podlegające prawu innego państwa członkowskiego, Dz. Urz. WE z 30 grudnia 1989 r., L 395/36.

${ }^{13}$ Dyrektywa 2005/56/WE Parlamentu Europejskiego i Rady z 26 października 2005 r. w sprawie transgranicznego łączenia się spółek kapitałowych, Dz. Urz. UE z 25 listopada 2005 r., L $310 / 1$.

14 J. Napierała, Europejskie prawo spótek, Warszawa 2013, s. 184. 
powinny być jawne. Poza czynnościa gromadzenia dokumentacji i informacji lub ich rejestrowania, istotnym elementem systemu działania krajowych rejestrów było także ogłoszenie danych w biuletynie krajowym (ujawnienie dokumentów i informacji). Podstawowym skutkiem ujawnienia danych stała się zaś ochrona osób działających w zaufaniu do tych danych ${ }^{15}$.

Z kolei wprowadzenie jedenastej dyrektywy Rady 89/666/EWG służyło dostarczeniu wspólnikom oraz osobom trzecim danych o oddziałach spółek, na zasadach analogicznych do tych obowiązujących w przypadku spółek córek zarejestrowanych w innym kraju niż spółka matka (motyw 4 dyrektywy) ${ }^{16}$. Potrzeba realizacji tego celu wynikła z faktu, że w wielu państwach członkowskich zakładanie oddziałów było obwarowane mniejszymi rygorami prawnymi, co prowadziło do osłabienia ochrony wspólników i osób trzecich ${ }^{17}$.

Ostatecznie dziesiąta dyrektywa odnosi się do jednej z postaci transgranicznej restrukturyzacji spółki, a mianowicie łączenia się spółek (cross-border merger). Zasadniczym celem dyrektywy jest ochrona wspólników i interesariuszy spółek kapitałowych zaangażowanych w proces łączenia. Stąd dyrektywa reguluje kolejne etapy procedury łączenia, określając uprawnienia i obowiązki podmiotów zaangażowanych $\mathrm{w}$ tę procedurę. Jednym z elementów procedury łączenia spółek jest wzajemna współpraca organów rejestrowych krajów, którym podlegały łączące się spółki. Jej przejawem jest, spoczywający na organie rejestrowym właściwym do dokonania wpisu spółki powstającej w wyniku połączenia transgranicznego, obowiązek powiadomienia o skuteczności połączenia wszystkich pozostałych organów rejestrowych, w których każda ze spółek łączących się miała obowiązek złożyć swoje dokumenty ${ }^{18}$.

Oddziaływanie przedstawionych dyrektyw na instytucje rejestrów handlowych można zatem sprowadzić do trzech płaszczyzn: zwiększanie transparentności działania spółek w obrocie międzynarodowym (jawność w sensie formalnym), umacnianie zaufania do informacji (jawność $w$ sensie materialnym) ${ }^{19}$ oraz usprawnianie procesów transgranicznych ${ }^{20}$. Należy nadmienić, że dyrektywy te przewidywały wprawdzie szczególne przypadki, w których organy były zobowiązane do współpracy, lecz forma realizacji tych obowiązków zależała wyłącznie od decyzji poszczególnych państw członkowskich.

${ }^{15}$ Art. 3 ust. 6-7 dyrektywy 2009/101/WE.

${ }^{16}$ Zob. A. Opalski, Europejskie prawo spótek, Warszawa 2010, s. 184-186.

${ }^{17} \mathrm{~W}$ praktyce dochodziło również do odwrotnych sytuacji, tzn. niektóre państwa członkowskie nakładały na oddziały dodatkowe obowiązki, które utrudniały wykonywanie swobody przedsiębiorczości na obszarze rynku wewnętrznego. Zob. wyrok Trybunału z 30 września 2003 r. w sprawie Inspire Art, C-167/01, Zb. Orz. 2003, s. I-10155, teza 71 i 72 . W tym orzeczeniu Trybunał wskazał, że dyrektywa 89/666/EWG wyznacza standard maksymalny w odniesieniu do treści ogłoszeń i pism handlowych oddziałów spółek zagranicznych, a w konsekwencji nałożenie dodatkowych obowiązków przez państwo członkowskie jest sprzeczne $\mathrm{z}$ prawem UE.

${ }_{18}$ Art. 13 akapit 2 dyrektywy 2005/56/WE.

${ }_{19} \mathrm{Na}$ ten obszar oddziałuja głównie pierwsza i jedenasta dyrektywa.

${ }^{20} \mathrm{~W}$ tym zakresie największe znaczenia ma obecnie dziesiąta dyrektywa. 


\section{CELE I CHARAKTER DYREKTYWY 2012/17/UE}

Podstawą prawną uchwalenia dyrektywy 2012/17/UE stał się art. 50 Traktatu o funkcjonowaniu Unii Europejskiej ${ }^{21}$. Zawarte w nim upoważnienie Parlamentu Europejskiego i Rady służy prawidłowemu i skutecznemu wykonywania swobody przedsiębiorczości (ang. freedom of establishment, niem. Niederlassungsfreiheit).

Dyrektywa 2012/17/UE nakierowana jest na realizację dwóch podstawowych celów. Pierwszym z nich jest ochrona interesów wspólników i osób trzecich, osiagana przez dostarczenie zainteresowanym jednostkom oficjalnych i łatwo dostępnych informacji o spółkach i ich oddziałach ${ }^{22}$. Z kolei za drugi cel uznać należy stworzenie ram prawnych i narzędzi komunikacji elektronicznej pomiędzy krajowymi rejestrami handlowymi ${ }^{23}$. Ponadto implementacja dyrektywy prowadzić ma do usprawnienia funkcjonowania samych spółek przez obniżanie kosztów wykonywania obowiązków rejestrowych, w tym tych związanych z procesami restrukturyzacyjnymi o charakterze transgranicznym, a w konsekwencji gwarantować efektywniejsze zarządzanie spółkami na rynku europejskim.

Omawiana dyrektywa ma co do zasady charakter minimalny, na co wskazują również niektóre z przepisów ${ }^{24}$, umożliwiające państwom członkowskim rozszerzenie zawartych tam gwarancji ochrony wspólników i interesariuszy spółki.

\section{UTWORZENIE SYSTEMU INTEGRACJI REJESTRÓW}

\section{Pojęcie systemu integracji rejestrów}

Elementem kluczowym dyrektywy 2012/17/UE jest utworzenie systemu integracji rejestrów ${ }^{25}$, który stanowi ogół narzędzi i instytucji pozwalających na sprawną wymianę informacji znajdujacych się w rejestrach handlowych państw członkowskich. Pojęcie systemu integracji rejestrów jest pojęciem zbiorczym, a jego zdefiniowanie w dyrektywie polega na wymienieniu części składowych tego systemu ${ }^{26}$. Dopiero te części pozwalają na odkrycie istoty systemu, który obligatoryjnie ${ }^{27}$ obejmuje:

1) rejestry handlowe państw członkowskich,

2) europejską centralną platformę,

3) portal e-Sprawiedliwość (e-Justice).

${ }^{21}$ Wersja skonsolidowana Dz. Urz. UE 2010, C 83/1 (dalej jako: TfUE).

${ }^{22}$ Motyw 1 dyrektywy 2012/17/UE.

${ }^{23}$ Motyw 9 dyrektywy 2012/17/UE.

${ }^{24}$ Np. art. 3 ust. 3 dyrektywy 2012/17/UE wprowadzający do dyrektywy 2009/101/WE art. 3c ust. 2.

${ }^{25}$ W rozporządzeniu wykonawczym Komisji (UE) 2015/884 z 8 czerwca 2015 r. (zob. przyp. 32), system integracji systemów określany jest jako system integracji rejestrów przedsiębiorców (BRIS).

${ }^{26}$ Zob. art. 3 ust. 4 dyrektywy 2012/17/UE wprowadzajacy do dyrektywy 2009/101/WE art. 4 a ust. 2 .

${ }^{27}$ Dodatkowo państwa członkowskie mogą fakultatywnie stworzyć krajowe punkty dostępu. 


\section{Schemat 1}

Schemat metody działania systemu integracji rejestrów

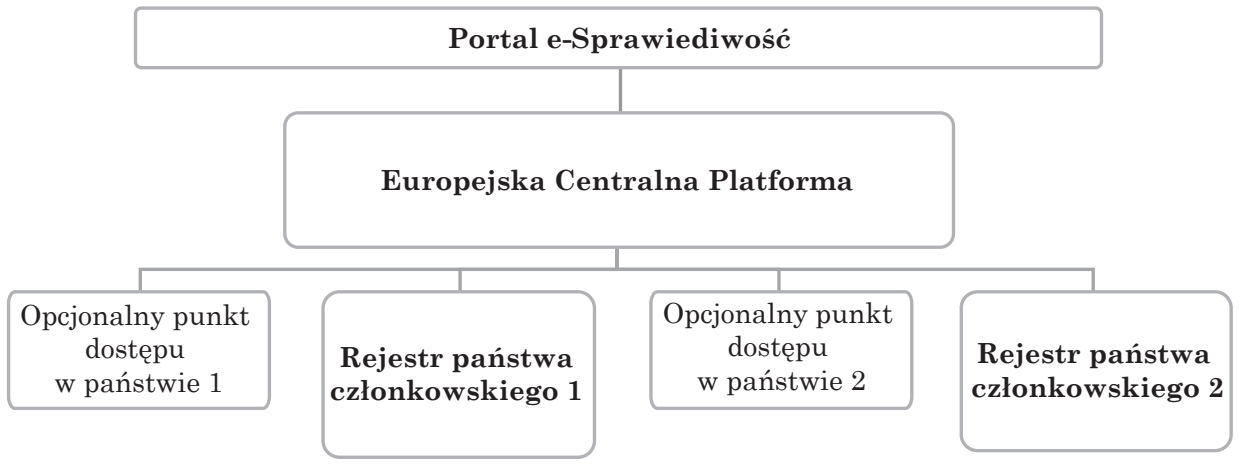

Źródło: opracowanie własne na podstawie rozporządzenia Komisji (UE) 2015/884 z 8 czerwca 2015 r.

\section{Rejestry handlowe państw członkowskich}

Poszczególne rejestry handlowe państw członkowskich są kluczowym elementem systemu. Z preambuły dyrektywy 2012/17/UE wynika, że celem stworzenia systemu integracji nie jest wprowadzenie centralnego rejestru, a wyłącznie połaczenie określonych instytucji ${ }^{28}$. Stąd kompetencje i zadania krajowych rejestrów, w tym gromadzenie danych o spółkach, pozostają zasadniczo niezmienne ${ }^{29}$, a sama współpraca między nimi odbywa się na zasadzie równoważności, gdyż dyrektywa nie wprowadza żadnego nowego i nadrzędnego organu. Także znaczenie czynności publikacji danych gromadzonych i wprowadzonych do rejestrów w danym biuletynie krajowym nie zostało zmodyfikowane i nadal to właśnie te dane mają wyłączne znaczenie dla ochrony osób działajacych w zaufaniu do nich.

Państwa członkowskie zobowiązane zostały do opracowania stosownych narzędzi (interfejs) służących połączeniu krajowych rejestrów z europejską centralna platforma ${ }^{30}$. Szczegóły dotyczące rozwiązań technicznych, które powinny być wdrożone przez państwa członkowskie w tym zakresie, ustalone zostały w rozporządzeniu wykonawczym Komisji z 8 czerwca 2015 r. ${ }^{31}$ Rozporządzenie określa metody i sposoby komunikacji, a także zobowiązuje państwa

${ }^{28}$ Tak też: D. A. Verse, M. Jur, Die Entwicklung des europäischen Gesellschaftsrechts im Jahr 2012, „EuZW - Europäische Zeitschrift für Wirtschaftsrecht” 2013, z. 9, s. 338; T. Kilian, op. cit., s. 185.

${ }^{29}$ Motyw 10 dyrektywy 2012/17/UE. Wewnętrzne systemy informatyczne rejestrów nie podlegają zmianie inter alia $\mathrm{w}$ zakresie zarządzania i przechowywania danych, ich udostępniania do celów krajowych oraz pobierania opłat.

${ }^{30}$ Art. 3 ust. 4 dyrektywy 2012/17/UE wprowadzający do dyrektywy 2009/101/WE art. 4a ust. 3.

${ }^{31}$ Rozporzadzenie wykonawcze Komisji (UE) 2015/884 z 8 czerwca 2015 r. ustanawiajace specyfikacje techniczne i procedury niezbędne dla systemu integracji rejestrów ustanowionego dyrektywą 2009/101/WE Parlamentu Europejskiego i Rady, Dz. Urz. UE z 10 czerwca 2015 r., L 144/1. 
członkowskie do zapewnienia odpowiednich środków bezpieczeństwa w odniesieniu do wymiany informacji. Komunikacja w przypadku systemu integracji rejestrów odbywa się za pośrednictwem platformy, a więc rejestry nie maja możliwości bezpośredniego przesyłania między sobą danych ${ }^{32}$. Przykładowo w sytuacji wymiany informacji między rejestrem spółki a rejestrem jej oddziału rejestr spółki bezzwłocznie udostępnia platformie informacje o wszczęciu i zakończeniu postępowania likwidacyjnego lub upadłościowego oraz o wykreśleniu spółki z rejestru, a następnie platforma na wniosek rejestru oddziału ujawnia mu te informacje ${ }^{33}$.

Zgodnie z nową treścią dyrektywy 2009/101/WE państwa członkowskie powinny udostępniać $\mathrm{w}$ ramach europejskiego systemu integracji rejestrów informacje oraz dokumenty o spółkach określone w jej art. 2. Jedynie w przypadku danych o procedurze likwidacji i upadłości spółki dyrektywa nakazuje przekazanie ich niezwłocznie. Należy jednak zaznaczyć, że warunkiem skuteczności implementacji dyrektywy jest, aby w ten sam sposób przekazywane były wszystkie dane. Natomiast za wadliwe uznać trzeba to, że dyrektywa nie zobowiązała państw członkowskich do notyfikowania do systemu integracji rejestrów informacji w formie ostrzeżeń o wszczęciu procedury wpisania zmian w rejestrze (o ile taka procedura została przewidziana w prawie danego kraju).

Do innych obowiązów państw członkowskich należy nadanie każdej spółce lub oddziałowi spółki identyfikatora, który służyć będzie do celów komunikacji w ramach systemu (EUID - European Unique Identifier). Identyfikator obowiązkowo obejmuje kod państwa, identyfikator rejestru, w którym zarejestrowana jest spółka lub oddział, oraz numer rejestracyjny nadany przez rejestr pochodzenia spółki lub oddziału ${ }^{34}$. Taka struktura identyfikatora pozwala uniknąć nałożenia na spółki obowiązku wprowadzenia dodatkowego oznaczenia w używanych przez spółkę pismach, formularzach czy na swoich stronach internetowych. Wystarczające pozostanie w tym zakresie stosowanie przez spółki krajowe numerów rejestrowych (w Polsce numer KRS).

\section{Europejska centralna platforma}

Europejska centralna platforma to system informatyczny, którego zadaniem jest przekazywanie danych pomiędzy rejestrami krajowymi, a także portalem e-Sprawiedliwość. W istocie jest ona interfejsem, umożliwiającym współpracę i wymianę informacji, a tym samym gwarantującym operacyjność całego systemu integracji rejestrów. Do korzystania z platformy zobowiązane zostały wszystkie państwa członkowskie.

Platforma nie jest odrębnym podmiotem prawa prywatnego ani publicznego, a wyłącznie „zestawem informatycznych narzędzi” ${ }^{35}$. Instytucja ta nie jest zatem uprawniona do wydawania we własnym imieniu jakichkolwiek decyzji,

\footnotetext{
${ }^{32}$ Załącznik do rozporządzenia wykonawczego Komisji 2015/884, pkt 1.

${ }^{33}$ Złożenie wniosku może odbywać się przez wcześniejsze wskazanie platformie, które spółki pozostają w kręgu zainteresowania rejestru oddziału.

${ }^{34}$ Załącznik do rozporządzenia wykonawczego Komisji 2015/884, pkt 8.

${ }^{35}$ Motyw 9 dyrektywy 2012/17/UE.
} 
a nawet ingerowania w treść przesyłanych jej danych. Nie gromadzi ona również danych merytorycznych dotyczących spółek. Wyjątkiem w tym zakresie są dane przekazywane w celu prawidłowego wykonywania funkcji platformy, tj. m.in. dane niezbędne do identyfikacji systemów podłączonych do platformy, podstawowe informacje o spółkach i oddziałach (firma i forma prawna spółki, nazwa rejestru oraz kraj rejestracji spółki, numer rejestrowy spółki, a także inne dane, które państwo członkowskie zdecyduje się przekazać) oraz identyfikator spółki lub oddziału.

Stworzenie platformy zostało powierzone Komisji UE, która może wykorzystać w tym celu własne zasoby lub zlecić skonstruowanie platformy osobie trzeciej. Nadzór nad funkcjonowaniem platformy pozostaje jednak domena Komisji UE i nie może być przekazany podmiotowi zewnętrznemu ${ }^{36}$.

\section{Portal e-Sprawiedliwość (e-Justice)}

Trzecim elementem systemu integracji rejestrów jest działający od 16 lipca 2010 r. portal e-Sprawiedliwość (e-Justice) ${ }^{37}$. Jest on jednym z elementów strategii budowy społeczeństwa informacyjnego w Europie oraz programu e-Sprawiedliwośćc ${ }^{38}$, którego główny cel stanowi stworzenie europejskiej przestrzeni sądowej ${ }^{39}$. Portal ma być przede wszystkim źródłem informacji i dostępu do europejskich oraz krajowych regulacji i procedur prawnych.

Wykorzystanie portalu w ramach europejskiego systemu integracji rejestrów handlowych polega na odbieraniu wnoszonych przez indywidualnych użytkowników pytań dotyczących gromadzonych w rejestrach krajowych informacji na temat spółek i ich oddziałów. W portalu przedstawiane są następnie wyniki wyszukiwania, które uwzględniaja podstawowe informacje na temat mocy prawnej dokumentów i informacji ujawnianych na podstawie przepisów państw członkowskich przyjętych zgodnie z dyrektywą 2009/101/WE ${ }^{40}$. Samo wyszukiwanie informacji w portalu w podstawowej formie ${ }^{41}$ odbywa się przez wybranie kraju, w którym siedzibę posiada spółka lub oddział, a następnie wpisanie firmy przedsiębiorstwa lub numeru rejestrowego.

Obowiązkiem państw członkowskich jest dostarczenie podstawowych informacji na temat spółek oraz klarowne wyjaśnienie przepisów dotyczących tego, w jakim stopniu osoby trzecie moga polegać na opublikowanych danych wpisanych do krajowego rejestru. Dane te publikowane sa przez Komisję w por-

${ }^{36}$ Art. 3 ust. 4 dyrektywy 2012/17/UE wprowadzający do dyrektywy 2009/101/WE art. 4b ust. 3 .

37 Dostępny na: https://e-justice.europa.eu/home.do [dostęp: 5.06.2016].

38 Wykaz innych działań został zamieszczony w załączniku do „Wieloletniego planu działania na lata 2009-2013 dotyczącego europejskiego e-prawa” (nr 2009/C75/01) z 31 marca 2009 r., Dz. Urz. UE 2009, C 75/1.

39 Szerzej L. Łuczak, Portal e-Justice jako element budowy społeczeństwa informacyjnego Unii Europejskiej, „E-mentor” 2013, nr 4, s. 81-83.

${ }^{40}$ Motyw 12 dyrektywy 2012/17/UE.

${ }^{41}$ Możliwe jest rozszerzenie kryteriów wyszukiwania. Zob. załącznik do rozporządzenia wykonawczego Komisji 2015/884, pkt 10. 
talu we wszystkich oficjalnych językach Unii ${ }^{42}$. W podobny sposób w portalu zamieszczane sa dokumenty wymienione w art. 2 dyrektywy 2009/101/ $\mathrm{WE}^{43}$. Komisja może wprowadzić dodatkowe opłaty za dostęp do dokumentów, nie mogą one jednak przekraczać kosztów administracyjnych ich udostępnienia ${ }^{44}$.

Utworzenie europejskiego portalu e-Sprawiedliwość, jako punktu kompleksowej obsługi obywateli państw członkowskich i osób zawodowo zajmujących się stosowaniem prawa, stanowi element centralizacji zadań związanych z dostarczaniem informacji o niektórych przedsiębiorstwach działających na terenie Unii. Jego podstawowa cechą jest wprowadzenie standardowego pakietu danych o każdym z krajowych systemów rejestrowych (etykiety danych) oraz funkcjonujacych w jego ramach spółek. Niemniej państwa członkowskie mogą rozszerzyć katalog danych dostępnych w portalu. To ostatnie rozwiązanie uznać należy za słuszne, gdyż umożliwia państwom stworzenie, w oczach międzynarodowych inwestorów, bardziej przejrzystych warunków prowadzenia działalności gospodarczej w ich krajach.

\section{POZOSTALE ZMIANY WPROWADZONE PRZEZ DYREKTYWĘ 2012/17/UE}

Poza kluczowymi dla funkcjonowania europejskiego systemu integracji zmianami przewidzianymi w dyrektywie 2009/101/WE, wprowadzony został do niej przepis art. 2a, który nakazuje państwom członkowskim zapewnienie środków umożliwiających dokonywanie zmian w rejestrach w terminie 21 od dnia ${ }^{45}$ złożenia wniosku o taką zmianę, wraz z kompletem potrzebnych do tego dokumentów. Wskazany termin ma wyłącznie charakter instrukcyjny ${ }^{46}$ oraz nie dotyczy dokumentów księgowych przekazywanych przez spółki za każdy rok budżetowy ${ }^{47}$.

Dziesiąta dyrektywa 2005/56/WE kształtująca procedurę transgranicznego łączenia spółek została zmodyfikowana w zakresie art. 13. Z nowego brzmienia tego przepisu wynika, że wymiana informacji pomiędzy rejestrami dokonuje się przy wykorzystaniu europejskiej centralnej platformy, co w zamyśle ma doprowadzić do przyspieszenia procedury łączenia.

Zmiany wprowadzone do jedenastej dyrektywy odnoszą się wyłącznie do sekcji I dyrektywy, a więc ram prawnych opracowanych dla oddziałów spółek podlegających prawu jednego z państw członkowskich ${ }^{48}$. Zasady przeka-

${ }^{42}$ Art. 3 ust. 3 dyrektywy 2012/17/UE wprowadzający do dyrektywy 2009/101/WE art. 3a i 3c ust. 2.

${ }^{43}$ Art. 3 ust. 3 dyrektywy 2012/17/UE wprowadzający do dyrektywy 2009/101/WE art. 3b.

${ }^{44}$ Art. 3 ust. 3 dyrektywy 2012/17/UE wprowadzający do dyrektywy 2009/101/WE art. 3c ust. 1.

${ }^{45} \mathrm{~W}$ projekcie dyrektywy 2012/17/UE termin ten wynosił 15 dni.

${ }^{46}$ Motyw 18 dyrektywy 2012/17/UE.

${ }^{47}$ Art. 3 ust. 1 dyrektywy 2012/17/UE wprowadzający do dyrektywy 2009/101/WE art. 2a.

${ }^{48}$ Sekcja II dyrektywy odnosi się do oddziałów założonych przez spółki podlegające prawu państw nienależących do UE. 
zywania i publikowania informacji o oddziałach spółek kształtują się w sposób analogiczny do tych właściwych dla samych spółek. Również podobnie jak spółki, każdy z oddziałów powinien mieć własny numer, który pozwoli na jego identyfikację $\mathrm{w}$ ramach europejskiego systemu integracji rejestrów ${ }^{49}$. Nowym rozwiązaniem jest ponadto wprowadzenie obowiązku przekazywania przez rejestry krajowe za pośrednictwem systemu integracji rejestrów, a konkretnie platformy, informacji o wszczęciu i zakończeniu postępowań likwidacyjnych lub upadłościowych oraz o wykreśleniu spółki z rejestru. Skutkiem odebrania przez kraj położenia oddziału informacji o rozwiązaniu spółki lub jej wykreśleniu z rejestru z innego powodu powinno być wykreślenie samego oddziału. To ostatnie nie dotyczy inter alia sytuacji, gdy spółka wykreślana jest na skutek przeprowadzania procedury restrukturyzacji spółki ${ }^{50}$.

\section{OCENA ZMIAN WPROWADZONYCH DYREKTYWĄ 2012/17/UE}

Integracja europejskich rejestrów handlowych rozpoczęła się już w latach sześćdziesiątych XX w. W pierwszej fazie zobowiązano kraje członkowskie do posiadania odpowiedniego rejestru, a także określenia minimalnego pakietu informacji, który taki rejestr powinien udostępniać (etap standaryzacji gromadzenia i udostępniania danych). Kolejny etap integracji to dostrzeżenie konieczności usprawnienia transgranicznych procesów restrukturyzacyjnych. W chwili obecnej to dyrektywa 2012/17/UE wyznacza stopień harmonizacji rejestrów spółek państw członkowskich na jednolitym rynku europejskim. Niewątpliwą korzyścią wynikająca z wprowadzenia tego aktu prawnego w życie jest nałożenie obowiązków na wszystkie kraje UE i stworzenie wspólnego rozwiązania na obszarze całej Unii. Nie oznacza to jednak, że implementacji dyrektywy towarzyszyć będzie istotne usprawnienie funkcjonowania spółek w obszarze europejskim, a to z następujących powodów.

Po pierwsze, europejski system integracji rejestrów zaprojektowany w dyrektywie 2012/17/UE zmierza jedynie do połączenia krajowych rejestrów i usprawnienia ich współpracy. Z kolei europejska centralna platforma, która ma być katalizatorem współpracy, jest wyłącznie zbiorem narzędzi i osób nią zarządzających. Platforma nie stanowi nowego organu administracji europejskiej, gdyż nie posiada odrębnej podmiotowości oraz nie dysponuje żadnymi środkami władczymi wobec rejestrów krajowych. Współpraca pomiędzy rejestrami krajowymi a platformą odbywa się przez przekazywanie poleceń przesłania określonych informacji za pośrednictwem zaprojektowanych systemów informatycznych. Równocześnie platforma nie jest w zasadzie uprawniona do gromadzenia danych o spółkach. W konsekwencji to rejestry krajowe wciąż pozostaja centralnym elementem szerszego europejskiego systemu rejestrów handlowych.

${ }^{49}$ Art. 1 ust. 1 dyrektywy 2012/17/UE wprowadzający do dyrektywy 89/666/EWG art. 1 ust. 3 i 4 .

${ }^{50}$ Art. 1 ust. 2 dyrektywy 2012/17/UE wprowadzający do dyrektywy 89/666/EWG art. 5a. 
Po drugie, funkcjonowanie systemu odnosi się wyłącznie do spółek kapitałowych wymienionych w art. 1 dyrektywy 2009/101/WE, a zatem nie obejmuje pozostałych podmiotów gospodarczych figurujacych w rejestrach krajowych. Nie jest możliwe również dobrowolne udostępnienie przez państwa członkowskie informacji o takich podmiotach za pośrednictwem platformy ${ }^{51}$. W rezultacie większość małych i średnich przedsiębiorstw nie będzie mogła korzystać z usprawnień oferowanych przez system integracji rejestrów.

Po trzecie, dane przedstawiane w portalu e-Sprawiedliwość - trzecim elemencie systemu integracji rejestrów - mająjedynie informacyjny charakter i nie posiadają wiążącej mocy prawnej. Przyczynę tego stanu rzeczy stanowi okoliczność, że nie znajduja do nich zastosowania przepisy o ochronie zaufania osób działajacych w dobrej wierze co do treści rejestrowych opublikowanych w biuletynach krajowych, zawarte w dyrektywie 2009/101/WE oraz 89/666/EWG. W konsekwencji nadal konieczne będzie każdorazowe sprawdzanie danych zawartych w biuletynach krajowych. $\mathrm{Z}$ tego również względu ewentualne wydruki z portalu e-Sprawiedliwość nie będą mogły być co do zasady uznane za wiarygodne w krajowych postępowaniach sądowych lub administracyjnych.

Po czwarte, istotne watpliwości wywołuje skuteczność i sprawność udostępniania dokumentów o spółkach za pośrednictwem europejskiego syste$\mathrm{mu}$. W ramach platformy nie gromadzi się bowiem tego rodzaju dokumentów, a więc każdorazowo konieczne jest wystapienie do rejestru krajowego o ich przesłanie. Zatem w sytuacji, w której danej osobie zależeć będzie na szybkim uzyskaniu określonych dokumentów, lepszym rozwiązaniem okazać się może bezpośrednie zwrócenie się do organów krajowych z pominięciem narzędzi unijnych.

Z uwagi na powyższe zmiany wprowadzone dyrektywą 2012/17/UE należy ocenić krytycznie, gdyż nie będą miały one istotnego znaczenia dla funkcjonowania jednolitego rynku. Jednym z rozwiązań, które faktycznie przyczyniłoby się do ułatwienia wykonywania swobody przedsiębiorczości, byłoby stworzenie wspólnotowego organu rejestrowego, którego zadania nie ograniczałyby się do przesyłania informacji i dokumentów, ale obejmowałyby również gromadzenie danych oraz prowadzenie niektórych transgranicznych postępowań. Dodatkowo należałoby nadać odpowiednią moc prawną informacjom upublicznianym w ramach portalu e-Sprawiedliwość, aby jednostki powołujacce się na te dane mogły skorzystać z ochrony prawnej w razie wystapienia niezgodności pomiędzy informacjami ujawnionymi w publikatorach krajowych i europejskim.

Innym możliwym rozwiązaniem jest rozszerzenie kompetencji rejestrów państw członkowskich, które działałyby nie tylko w ramach krajowych uprawnień, ale w niektórych sytuacjach mogłyby wydawać wiążące decyzje innym rejestrom. Już obecnie decyzja o zarejestrowaniu spółki rodzi konieczność uznania jej w innych krajach członkowskich ${ }^{52}$. Kompetencje te należałoby rozszerzyć o możliwość przeprowadzania procedury poszczególnych

51 Zob. załącznik do rozporządzenia wykonawczego Komisji 2015/884, pkt 5.1.

${ }_{52}$ Zob. wyrok Trybunału z 5 listopada 2002 r. w sprawie C-208/00 - Überseering BV vs. Nordic Construction Company Baumanagement GmbH, Zb. Orz. 2002, s. I-09919, pkt 82. 
rodzajów restrukturyzacji transgranicznych ${ }^{53}$ oraz rejestrowania spółek podlegających prawu spółek jednego z państw członkowskich. W ten sposób krajowe organy rejestrowe stałyby się również organami europejskiego systemu rejestrowego.

\section{IMPLEMENTACJA DYREKTYWY 2012/17/UE DO PRAWA POLSKIEGO}

Implementacja dyrektywy 2012/17/UE do prawa polskiego nastapić powinna w ramach trzech obszarów prawnych: ustawy z 2 lipca 2004 r. o swobodzie działalności gospodarczej ${ }^{54}$, ustawy z 15 września 2000 r. - Kodeks spółek handlowych ${ }^{55}$ oraz przede wszystkim ustawy z 20 sierpnia 1997 r. o Krajowym Rejestrze Sądowym ${ }^{56}$. W przypadku przywołanego w pierwszej kolejności aktu prawnego ${ }^{57}$ niezbędne stanie się objęcie zakresem jego regulacji procedury przymusowego, tj. niezależnego od woli osoby upoważnionej w ramach funkcjonowania oddziału, wykreślenia oddziału na skutek wykreślenia spółki założycielki oddziału z rejestru państwa członkowskiego. Elementem koniecznym takiej procedury będzie zaś zbadanie, na jakiej podstawie doszło do wykreślenia spółki założycielki oddziału ${ }^{58}$. Czynność ta powinna mieścić się w zakresie kompetencji sądu rejestrowego, działajacego ex officio, do którego za pośrednictwem europejskiej centralnej platformy trafiła stosowna informacja. Należy dodać, że dyrektywa 2012/17/UE nie przewiduje obowiązku lub upoważnienia do wprowadzenia specjalnego postępowania likwidacyjnego oddziału.

\footnotetext{
${ }^{53}$ Analogiczne rozwiązanie zostało przewidziane w art. 4 ust. 2 tzw. trzynastej dyrektywy Parlamentu Europejskiego i Rady 2004/25/WE z 21 kwietnia 2004 r. w sprawie ofert przejęcia, Dz. Urz. WE z 30 kwietnia 2004 r., L 142/12, w którym to kompetencja organów nadzoru nad ofertami przejęcia została co do zasady powierzona organowi państwa członkowskiego, w którym swoją siedzibę statutową ma spółka będąca przedmiotem oferty.

${ }^{54}$ Dz. U. 2004, Nr 173, poz. 1807 ze zm.

55 Dz. U. 2000, Nr 94, poz. 1037 ze zm. (dalej jako: k.s.h.).

${ }_{56}$ Dz. U. 1997, Nr 121, poz. 769 ze zm.

${ }_{57}$ Sejm VII kadencji podjął pracę nad rządowym projektem ustawy o działalności gospodarczej, który zgodnie z uzasadnieniem projektu miał obejmować implementację dyrektywy 2012/17/UE (druk nr 3807 z 3 sierpnia 2015 r., s. 24-26). Artykuł 31 projektu przewidywał procedurę zamknięcia oddziału przedsiębiorcy zagranicznego na skutek decyzji tego przedsiębiorcy. Należy jednak uznać, że przepis ten całkowicie rozmija się z omawianą tu dyrektywa, która wprowadza obowiązek uregulowania m.in. postępowania na skutek wykreślenia spółki, założycielki oddziału, $\mathrm{z}$ rejestru, tj. formy postępowania przymusowego.

58 Zob. art. 5a ust. 5 dyrektywy 2012/17/UE. Implementacja tego przepisu będzie wymagała respektowania skuteczności i wykonalności - w zależności od modelu funkcjonowania rejestrów handlowych - decyzji o charakterze technicznym (wykreślenie z rejestru) lub administracyjnym bądź orzeczenia sądowego z jednego państwa członkowskiego w pozostałych państwach członkowskich. Z tego powodu polski sąd rejestrowy nie będzie mógł badać zasadności wykreślenia spółki z rejestru w innym państwie członkowskim, a jedynie skutki, jakie to za sobą niesie. Por. T. Kilian, op. cit., s. 185; P. Ries, Die europaweite Verknüpfung der Handelsregister - Risiken und Chancen, „ZIP - Zeitschrift für Wirtschaftsrechts” 2013, z. 18, s. 869.
} 
Zmiany w przepisach k.s.h. nie będą miały charakteru kompleksowego i właściwie ograniczą się do doprecyzowania art. $516^{13} \S 4$, który z oczywistych względów nie uwzględnia obecnie istnienia europejskiej centralnej platformy.

Za najbardziej istotne uznać należy zmiany, które zostaną wprowadzone do ustawy o Krajowym Rejestrze Sąowym. Przede wszystkim obejmować one będą zapewnienie interoperacyjności polskiej Centralnej Informacji Krajowego Rejestru Sądowego z europejską centralną platformą w zakresie przesyłania informacji i odpowiednich dokumentó $\mathrm{w}^{59}$, w tym oznaczenia polskich spółek kapitałowych i spółki komandytowo-akcyjnej specjalnym numerem identyfikacyjnym oraz upoważnienia i zobowiązania polskich sąów rejestrowych do przesłania stosownych informacji do europejskiego systemu. Ponadto nie mniejsze znaczenie przypisać trzeba sformułowaniu w sposób przejrzysty i przystępny informacji o znaczeniu danych ujawnionych w krajowym publicznym biuletynie (etykiety danych), a publikowanych w portalu e-Sprawiedliwość, określeniu zakresu danych o spółkach krajowych przesyłanych na europejską centralną platformę, a także usprawnieniu procedur elektronicznego przekazywania tam dokumentów rejestrowych. Wszystkie te działania służyć będą podniesieniu konkurencyjności zarówno polskich przedsiębiorców, jak i polskiego obszaru prawnego w zakresie prowadzenia działalności gospodarczej.

\section{PODSUMOWANIE}

Zmiany wprowadzone w ostatnich kilku latach w prawie europejskim doprowadziły do umocnienia współpracy pomiędzy organami rejestrowymi poszczególnych krajów członkowskich. Stworzenie wspólnych rozwiązań technologicznych na szczeblu europejskim pozwoli również już w niedługiej przyszłości (połowa 2017 r.) na szybszy dostęp do informacji o spółkach i ich oddziałach prowadzących działalność gospodarczą na terenie Unii. Niemniej wszystkie te zmiany maja charakter zachowawczy ${ }^{60}$ i nie przyczyniaja się do budowy scentralizowanego systemu rejestrów handlowych, który przejąłby niektóre kompetencje rejestrów handlowych. Istnienie takiego systemu, w ocenie autora opracowania, istotnie wpłynęłoby na pełniejszą realizację zasady swobody przedsiębiorczości (art. 54 w zw. z 49 TfUE), a przede wszystkim doprowadziłoby do obniżenia kosztów administracyjnych prowadzenia działalności gospodarczej na terenie Unii i zwiększenia w ten sposób konkurencyjności przedsiębiorstw europejskich.

\footnotetext{
${ }^{59}$ Wymagać to będzie również wydania stosownych rozporządzeń wykonawczych na podstawie upoważnienia zawartego w ustawie.

${ }^{60}$ Zwrócono na to uwagę w opinii Europejskiego Komitetu Ekonomiczno-Społecznego z 15 czerwca 2011 r.: Proposal for a Directive of the European Parliament and of the Council amending Directives 89/666/EEC, 2005/56/EC and 2009/101/EC as regards the interconnection of central, commercial and companies registers, COM (2011), 79 final, s. 6, http://eur-lex.europa.eu/legalcontent/ EN/TXT/?uri=CELEX:52011AE 0989 [dostęp: 5.06.2016].
} 
W kwestii implementacji dyrektywy 2012/17/UE do prawa polskiego podkreślić trzeba, że przedstawione w opracowaniu rozwiązania mają doniosłe znaczenie dla ułatwienia polskim przedsiębiorcom prowadzenia działalności gospodarczej w Europie. Jednocześnie dyrektywa 2012/17/UE dopuszcza możliwość podwyższenia standardów służących realizacji celów dyrektywy, co stanowi szansę na wystapienie zjawiska konkurencji regulacyjnej pomiędzy poszczególnymi krajami członkowskimi, prowadzącej do zwiększenia przejrzystości działania spółek w Europie. Im lepiej polskie instytucje będą współpracować z systemem integracji rejestrów, tym większym zaufaniem będą cieszyć się polskie spółki w Europie. Stąd prawidłowa implementacja dyrektywy 2012/17/UE przez Polskę powinna uwzględniać rozszerzenie standardów określonych w tym akcie prawnym, gdyż dzięki temu może dojść do upowszechnienia w Europie polskich korporacyjnych form prawnych i zwiększenia ich szans na odniesienie sukcesu gospodarczego na jednolitym rynku.

mgr Ariel Mucha

Uniwersytet Jagielloński

ariel.mucha@doctoral.uj.edu.pl

THE UE SYSTEM OF INTERCONNECTION OF REGISTERS FOLLOWING THE ADOPTION OF DIRECTIVE 2012/17/EU OF THE EUROPEAN PARLIAMENT AND OF THE COUNCIL

OF 13 JUNE 2012

Sum mary

This paper presents an analysis and evaluation of Directive 2012/17/EU of the European Parliament and of the Council of 13 June 2012 and its implementation into Polish law, including its effect on domestic companies. Directive 2012/17/EU aims to create a legal framework for the interconnection of business registers operating in the EU Member States. Within this framework, the interconnection of business registers serves to improve the exchange of information among different commercial registers of companies. These registers provide information about companies established in the European Economic Area and their foreign branches and facilitate operations of cross-border mergers. The key element of the Directive is a 'system of interconnection of registers' which will consist of central, commercial registers of the Member States, the European central platform and the European e-Justice portal. However, the most important role will be still played by national registers, and the remaining elements of the system will only provide tools for interconnection of registers. Thus, changes introduced by Directive 2012/17/EU do not lead to any significant alterations within the European area. This does not mean, however, that the Polish legislator has not a vested interest in the implementation of this Directive. An appropriate amendment of the law may increase the competitiveness of the Polish company law system and companies incorporated pursuant to this law. 